УДК $32+341.324$

https://doi.org/10.34142/24130060.2019.17.1.15

\title{
СУЧАСНІ ОКУПАЦІЙНІ РЕЖИМИ: ОГЛЯД КОНЦЕПТУАЛЬНИХ ІНТЕРПРЕТАЦІЙ
}

\author{
A.C. Размстасв \\ Харківський національний педагогічний університет імені Г.С. Сковороди
}

У статті розглянуто основні конщепиії окупації, розроблені фахівцями в галузі права та політичної науки наприкінці XX - на початку XXI століття: пролонговану, трансформаційну, гуманітарну та опосередковану окупації. Окреслено їх спільні та відмінні риси, а також взаємозв'язок з класичною доктриною окупаиії. Здійснено на їх основі концептуальний розподіл сучасних окупаційних режимів. Зроблено висновок, щуо нові нормативні рамки здійснення влади окупантами є спробою компромісу між базовими обмеженнями класичної доктрини та реальною політикою акторів окупаційних режимів.

Ключові слова: конщепція окупаџії, окупаційний режим, принщип збереження, статус окупанта, ефективний контроль, пролонгована окупація, трансформаційна окупація, гуманітарна окупачія, окупація через третіх осіб.

\section{СОВРЕМЕННЫЕ ОККУПАЦИОННЫЕ РЕЖИМЫ: ОБЗОР КОНЦЕПТУАЛЬНЫХ ИНТЕРПРЕТАЦИЙ}

\section{А.С. Разметаев}

В статье рассмотрень основные конщепции оккупащии, разработанные специалистами в области права и политической науки в конще XX - начале XXI века: пролонгированная, трансформаџионная, гуманитарная и опосредованная оккупации. Определены их общие и отличительные черты, а такље взаимосвязь с классической доктриной оккупации. Осуществлено на их основе конщептуальное разделение современных оккупационных режимов. Сделан вывод, что новые нормативные рамки осуществления власти оккупантами являются попыткой компромисса между базовыми ограничениями классической доктрины и реальной политикой акторов оккупационных режимов.

Ключевые слова: концепщия оккупации, оккупационный режим, принции сохранения, статус оккупанта, эффективный контроль, пролонгированная оккупация, трансформаџионная оккупаџия, гуманитарная оккупащия, опосредованная оккупаџия

\section{MODERN OCCUPATION REGIMES: OVERVIEW OF CONCEPTUAL INTERPRETATIONS}

\section{A. Razmietaiev}

The article gives an overview of basic concepts of occupation, developed by specialists in the fields of modern political science and jurisprudence in the end of the $20^{\text {th }}$ - at the beginning of the $21^{\text {st }}$ cent.: prolonged, transformative, humanitarian occupations and occupation by proxy. Their common features and differences, as well as relation to the classic doctrine of occupation have been outlined. 
Modern conceptual approaches were compared on the basis of the three basic principles of any occupation: effective control of territories, conservationist principle and temporary status of an occupant. It has been showed that under the influence of the politics of occupants new normative models of occupations are formed. On the other hand, comparative analysis witnesses that modern occupation regimes are often determined by the concepts, within which framework the politics of occupants is implemented. In this respect concepts turn into practical models, by which an occupant is guided when exercising power on occupied territories.

Using the above occupation concepts the dominating types of occupation regimes of the $21^{\text {st }}$ cent. have been pointed out. It has been found that transformative and humanitarian occupations became the government models, which tried solving a difficult dilemma between restrictions of the law of occupation and transformative goals of actors of occupation regimes in practice. Though, as a rule, the duration of such occupation regimes never exceeded 3-5 years. In their turn, prolonged occupations and occupations by proxy are empirical reality of the politics of certain states, which proceed using military interventions and occupations of foreign territories as a mechanism of securing their own interests using power. Obvious illegitimacy of power of such occupants demands from international community using effective coercive measures in order to stop prolonged occupation regimes and restoring sovereignty of affected states.

A conclusion is made that all normative models of execution of power by occupants is an attempt of gaining a compromise between basic restrictions of the classical doctrine and a real politics of occupation regimes actors.

Key words: occupation conception, occupation regime, conservationist principle, occupant's status, effective control, prolonged occupation, transformative occupation, humanitarian occupation, occupation by proxy.

Постановка проблеми. Окупаційні режими як політична реальність сучасності існують у складному діалектичному зв'язку 3 міжнародним правом. 3 одного боку, під впливом політики окупантів формуються нові нормативні моделі окупацій. 3 іншого - сучасні окупаційні режими нерідко детермінуються концепціями, в рамках яких реалізується окупаційна політика. В цьому сенсі концепції перетворюються на практичні моделі, якими керується окупант при здійсненні влади на окупованих територіях. У XXI ст. невиправдана гнучкість нормативних «дозволів» нівелює обмежувальні рамки окупанта як тимчасового опікуна суверенної території іншої держави.

\section{Аналіз останніх досліджень і публікацій. Феномену окупації} присвячені праці Е. Бенвеністі, Й. Дінштейна, Е. Арато, Н. Бута, А. Каркано, Дж. Коен, К. Ламмерса, С. Ратнера, А. Робертса, П. Стьорка, Г. Фокса. Окремо слід виділити періодичні публікації фахівців Міжнародного комітету Червоного Хреста (С. Віте, М. Сассолі, Т. Фераро) щодо тлумачення різних аспектів окупації в контексті міжнародного гуманітарного права. Питання 
воєнної окупації через призму російсько-української війни охоплені працями таких вітчизняних вчених, як П. Гай-Нижник, М. Гнатовський, В. Горбулін, О. Задорожній, Г. Перепелиця, С. Прийдун, В. Філіпчук.

Водночас, для вітчизняної науки залишаються маловідомими теоретичні розробки іноземних вчених щодо концептуального осмислення сучасних окупаційних режимів і визначення нормативних підстав політики окупантів. Відповідно, метою статті є опис концепцій окупації, які отримали визнання в іноземній політичній й правовій літературі, та здійснення на їх основі концептуального розподілу сучасних окупаційних режимів.

Виклад основного матеріалу. Класична «Гаазька» доктрина окупації, сформована в дискусіях міждержавних конференцій у Брюсселі (1874 р.) та Гаазі (1899 і 1907 рр.), результатом яких стало прийняття Положення про закони і звичаї війни на суходолі 1907 р. (далі - Гаазьке Положення), що започаткувало окупаційне право, доповнене пізніше IV Женевською конвенцією 1949 р., передбачає три базових параметри, яким має відповідати кожна воєнна окупація:

1. Принцип ефективного територіального контролю окупованих територій (далі - принцип ефективного контролю). Відповідно до ст. 42 Гаазького Положення, територія визнається окупованою, якщо вона фактично перебуває під владою армії супротивника. Окупація поширюється лише на ту територію, де така влада встановлена і здатна виконувати свої функції.

2. Принцип збереження існуючого політичного порядку (далі принцип збереження) означає, що з фактичним переходом до рук окупанта повноважень легітимної влади він повинен дотримуватись існуючих у країні законів, за виключенням, коли це абсолютно неможливо (ст. 43 Гаазького Положення 1907).

3. Принцип тимчасовості влади окупанта. Окупація з самого початку була задумана як тимчасовий режим, що існує до укладення мирної угоди між воюючими сторонами (Benvenisti, 2012, p. 20). 
Однак, політика окупантів завжди відхилялась від нормативних рамок Гаазької доктрини, що стало особливо помітним після Другої світової війни. Особливо загрозливою тенденцією сучасності стала інституціоналізація довготривалих окупаційних режимів, що $є$ предметом дискусій політиків, дипломатів, вчених та юристів.

Пролонгована окупація (prolonged occupation). Перша спроба концептуального осмислення окупаційних режимів, що явно порушували тимчасовий статус окупантів, зроблена у 1990 р. професором Оксфордського університету А. Робертсом. Воєнна окупація, зазначає вчений, це тимчасовий стан, який може завершитись внаслідок зміни стану війни або може бути перетворений в якийсь інший статус у результаті переговорів, проведених після завершення або найближчим часом після завершення війни. Проте вчений наголошує, що стан окупації може тривалий час існувати навіть після формального завершення війни. Багато епізодів, особливо після Другої світової війни, ставлять під сумнів припущення про те, що окупації $\epsilon$ короткочасними (Roberts, 1990, p. 47).

Пролонгованою, на думку А. Робертса (1990, р. 47), може вважатись окупація, яка відповідає двом критеріям: триває більше 5 років та існує у відносно мирний період, коли не ведуться активні бойові дії.

До пролонгованих окупацій вчений відніс: союзницькі окупації Німеччини та Японії після Другої світової війни (тривалістю 6 та 10 років, відповідно), південноафриканську окупацію Намібії 1960-80рp., турецьку окупацію Північного Кіпру та окупацію Західної Сахари Марокко (тривають 3 середини 1970-х рр.), в’єтнамську окупацію Камбоджі 1978-1989 рр., радянську окупацію Афганістану $1978-1989$ р.p., а також ізраїльську окупацію палестинських і сирійських територій, яка продовжується з 1967 р. (Roberts, 1990, pp. 44, 48-51).

Вчений вважає, що принцип збереження у пролонгованих окупаціях повинен бути гнучким. Під час окупації, що існує тривалий час, пише він, може виникнути багато практичних проблем, які не допускають простих 
тимчасових рішень, заснованих на ідеї збереження status quo: можуть знадобитися рішення з таких питань, як будівництво доріг, вища освіта, водопостачання, виробництво електроенергії та інтеграція до мінливих міжнародних ринків. Такі рішення, незважаючи на радикальні i довгострокові зміни, не можуть бути відкладені на невизначений термін. Політична система окупованих територій, на думку вченого, також не може перебувати у застиглому стані, бо у противному випадку відкладення створення політичних інститутів призведе до того, що все населення опиниться в правовому та політичному підвішеному стані (Roberts, 1990, p. 52).

Детально розбираючи особливості ізраїльського окупаційного режиму на палестинських i сирійських територіях як найбільш тривалої та проблемної окупації сучасності, А. Робертс позитивно оцінює політику ізраїльської влади в таких питаннях, як, наприклад, скасування смертної кари за вбивства. Водночас, вчений критикує практику створення ізраїльських поселень на окупованих територіях й експропріацію земель палестинців, яка, вочевидь, тільки сприяє інституціоналізації окупаційного режиму на цих територіях. Позиція Верховного суду Ізраїлю про те, що постійний характер поселень не суперечить тимчасовому характеру окупації, викликає у вченого обгрунтований скептицизм (Roberts, 1990, p. 94).

Отже, як можна побачити, запропонована А. Робертсом модель пролонгованої окупації не легітимізує постійний ефективний контроль окупанта, що свідчить про прихильність цієї моделі принципу тимчасовості його влади на окупованих територіях. Пролонгована окупація, на думку вченого, як і будь-яка інша, має завершитись в результаті переговорів i укладення формального договору, що припиняє окупацію, або самовизначення населення окупованих територій шляхом створення ним автономних політичних інститутів, які приймають на себе все більшу відповідальність, та призводять до суверенітету й незалежності (Roberts, 1990, p. 102). 
Водночас, застосування цієї концепції на практиці породжує багато колізій. Як зауважує професор Лондонської школи економіки К. Чінкін, при пролонгованій окупації існує дилема між принципом збереження, який не дозволяє окупанту змінювати діючі закони, та правовим вакуумом, що виникає на окупованій території, внаслідок чого вона стає соціально й економічно нерозвиненою. Сама по собі пролонгація окупації, на думку дослідниці, дає гарні підстави для того, щоб стверджувати, що окупанти повинні мати більш широкі повноваження, що дозволяють розвивати політичні та економічні інститути (Chinkin, 2008). Однак, вона відразу застерігає, що дозвіл - навіть вимога - щоб окупант здійснював програми розвитку, правові або інші соціальні програми, може бути ситуацією, занадто близькою до анексії (Chinkin, 2008). Відомий дослідник окупаційного права Е. Бенвеністі з цього приводу слушно зауважує, що «визнання збільшення повноважень окупанта буде означати фактично надати окупанту майже всі повноваження сучасного суверенного уряду, якими він може володіти» (2012, p. 246).

В цілому, концепція пролонгованої окупації $є$ певною спробою осмислити науковим шляхом факт існування довготривалих окупаційних режимів у сучасному світі та намаганням виправдати їх тривалість необхідністю здійснення окупантом програм соціального-економічного розвитку окупованих територій до політичного врегулювання їх статусу. Трансформаційна політика акторів пролонгованого окупаційного режиму, на думку автора концепції (Roberts, 1990, p. 96), повинна визначатись інтересами та потребами окупованого населення.

Разом 3 тим, ця концепція не дала відповідей на питання про межі здійснення окупантом владних повноважень, збалансування інтересів окупанта та законного суверена, часових рамок пролонгованих окупаційних режимів, забезпечення дієвих механізмів впливу міжнародного співтовариства на акторів цих режимів. Анексія у 2014 р. Російською Федерацією території Криму знову ставить на порядок денний концепцію 
пролонгованої окупації, яка вже не виглядає архаїкою, що інтерпретувала політичну дійсність періоду Холодної війни.

\section{Tрансформаційна окупація (transformative осcupation). Воєнна} інтервенція й окупація Сполученими Штатами та їх союзниками Іраку у 2003 р. викликала багато дискусійних питань щодо меж втручання однієї держави у суверенітет іншої. Взагалі ідея зміни окупантом політичної системи завойованої держави не нова. Е. Бенвеністі наводить приклад окупації Російською імперією Болгарії у 1878-1878 рр. в ході російсько-турецької війни, де реорганізація місцевої адміністративної системи виправдовувалась неможливістю відновити встановлений Туреччиною режим, від якого, за твердженням тодішнього російського дипломата Ф. де Мартенса, «болгари страждали на протязі століть» (2012, р. 40). А. Робертс (2006, р. 587), окрім тривалості союзницьких окупацій Німеччини та Японії після Другої світової війни, підкреслив їх трансформаційну діяльність, зокрема, скасування фашистських законів. Інтервенцію США до Афганістану у 2001 p. та повалення режиму талібів вчений також характеризує як короткочасну трансформаційну окупацію (Roberts, 1990, p. 604).

Але вперше за часів існування Організації Обєднаних Націй було створено прецедент, коли іноземна держава окупувала іншу країну без санкції ООН, а потім отримала мандат на здійснення широких окупаційних повноважень, що явно виходили за межі традиційного права окупації. У резолюції 1483 від 22 травня 2003 р. Рада Безпеки ООН визнала США та Великобританію окупаційними державами та закликала створену окупантами Коаліційну тимчасову адміністрацію «сприяти благополуччю народу Іраку шляхом ефективного управління територією, в тому числі, зокрема, за допомогою діяльності з відновлення умов безпеки і стабільності та створення умов, в яких іракський народ може вільно визначити своє політичне майбутнє» (United Nations Security Council, 2003).

Окупація Іраку стала каталізатором концептуального обгрунтування «трансформаційної окупації», яке пов’язують з ім’ям американського юриста 
й дипломата Д. Шеффера. У своїй статті «За межами окупаційного права» він зазначив, що окупаційне право не повинно тлумачитися як заохочення або полегшення пролонгованої окупації, оскільки було розроблено з метою заохочення тимчасової окупації (Scheffer, 2003, p. 848). Основна передумова окупаційного права, відмічає Д. Шеффер (2003, р. 851), полягає в тому, щоб обмежити окупаційну владу гуманітарними цілями, які по суті зберігають status quo, а не наділяють окупаційну владу правом трансформації території, яку вона займає. В той же час, суспільства, що перебувають в стані політичного, судового та економічного колапсу чи суспільства, які страждають від внутрішнього режиму репресій, вимагають набагато більшої свободи для трансформаційного розвитку, ніж очікувалося б в рамках традиційних інструментів окупаційного права. Суспільство, стверджує він, «може зажадати революційних змін у своїй економіці (в тому числі в умовах жорсткого капіталізму), суворої реалізації міжнародних стандартів у галузі прав людини, нової конституції та судової системи і нової політичної структури (швидше за все, погодиться з принципами демократії), які ніколи не передбачались окупаційним правом або внутрішнім законодавством на окупованій території» (Scheffer, 2003, p. 849).

У підсумку, Д. Шеффер пропонує термін «трансформаційна окупація», під якою він розуміє військово-політичну допомогу суспільству, що прагне демократичних перетворень, однією чи кількома іноземними силами, діючими під егідою Ради Безпеки ООН або навіть без чіткої згоди членів Радбезу, якщо існує «загроза виживання чи неминуче прагнення цільового суспільства до самовизначення» (2003, p. 859).

3 точки зору ідеології лібералізму, ціль демократичних перетворень та усунення авторитарних режимів може стати як легітимною підставою зовнішнього втручання, так і виправданням трансформаційної політики на території іншої суверенної держави. Г. Куц відзначає трансформаційний потенціал лібералізму у загальносвітовому масштабі, підкреслюючи, що 
«ліберальна демократія має набути широкого визнання в якості глобальної моделі політичної організації» (2011, с. 634).

Прибічник неореалістичного підходу Н. Бута, напроти, вважає трансформаційну окупацію «антиномією демократичного нав'язування в умовах воєнної диктатури» (2005, р. 724). За висновком вченого, успіх трансформаційної окупації є нестійким і залежить від якості підкорення, якого досягає окупант над окупованою територією, проте парадокс полягає в тому, що «чим більше окупант намагається підкорити собі, тим складнішою стає легітимація його влади» (Bhuta, 2005, p. 739). Спробу США реалізувати трансформаційну модель воєнної окупації в Іраку вчений розцінює як невдалу саме через неможливість вирішення дилеми між підкоренням і легітимацією (Bhuta, 2005, p. 724).

Е. Бенвеністі (2012, р. 269), описуючи окупацію Іраку, вказав на те, що примусовий перехід іракського суспільства до демократії $є$, мабуть, найбільш радикальним відхиленням від принципу збереження. Іракська конституція була нав'язана окупантами та не залишила іракському народу іншого вибору, аніж взяти участь у переході до демократії, як це передбачалось іноземними акторами.

На думку Дж. Коен, принцип збереження вимагає, щоб істотні перетворення, що відбуваються в ході окупації, здійснювались місцевим населенням через своїх представників, а не окупаційною владою. Завдання окупанта - полегшити цей процес шляхом забезпечення порядку та стабільності на окупованих територіях. Разом з цим, перехід витісненого суверенітету до «народу» означає, що суверенітет останнього «призупиняється» на час окупації, доки представники народу не сформують власний уряд (Cohen, 2007, p. 525).

Порушення принципу збереження та нав'язування окупантами ліберальних законів без широкої місцевої підтримки не призвели до встановлення стабільного демократичного режиму в Іраку на кшталт західних демократій. За словами Г. Кісінджера, впровадження 
плюралістичної демократії замість жорстокого правління Саддама Хусейна виявилося набагато складнішим завданням, ніж повалення диктатора. Ірак продовжує виконувати функції поля бою, куди насувається регіональне сектантське змагання, його уряд схиляється до Ірану, елементи сунітського населення перебувають у збройній опозиції до уряду, обидві сторони підтримують джихадистів (Кісінджер, 2017, с. 260-261).

Небезпека трансформаційної окупації полягає в тому, що вона потенційно здатна не тільки трансформувати, а й повністю знищити політичну систему окупованого суспільства, взамін не запропонуваши ефективних політичних інститутів. Однак іï безсумнівною перевагою, порівняно з пролонгованими окупаціями, є визнання тимчасового характеру окупації. Тривалість трансформаційних окупацій Іраку (2003-2005) та Афганістану (2001) є незрівнянно меншою, аніж стійких окупаційних режимів Ізраїлю в Палестині чи Марокко у Західній Сахарі.

Гуманімарна окупація (humanitarian осcupation). У своїй однойменній праці американський вчений Г. Фокс запропонував термін «гуманітарна окупація», тобто «перейняття повноважень управління державою або іiі частиною міжнародним суб'єктом 3 метою створення ліберального, демократичного порядку» (2008, р. 4). Г. Фокс (2008, р. 2) наводить приклади Косово, Боснії, Східного Тимору та Східної Славонії, де $з$ середини 1990-х рр. ООН та інші міжнародні органи повністю замінили місцеву владу, фактично ставши національними урядами на цих територіях. Гуманітарна окупація (на відміну від інших вживаних термінів: «міжнародна територіальна адміністрація», «інтернаціоналізована територія», «нео-опіка» тощо), на думку вченого, найбільш точно передає суть миротворчих місій ООН 3 перехідного управління територіями, що серйозно постраждали внаслідок збройних конфліктів. По-перше, ці місії мали гуманітарну ціль припинення порушень прав людини, реформування інститутів управління, відновлення мирного співіснування між конфліктуючими групами. А подруге, влада міжнародних адміністраторів вельми схожа 3 владою 
традиційних воєнних окупантів: як перші, так i другі, $\epsilon$ сторонніми суб’єктами на контрольованій території, привласнюють повноваження верховної влади та мають тимчасовий статус (Fox, 2008, pp. 3-4).

Головною метою, що поєднувала усі резолюції ООН із запровадження міжнародних перехідних адміністрацій, було відновлення постраждалих в ході збройних конфліктів держав, при цьому у переважній більшості випадків декларувалось збереження їх суверенітету та територіальної цілісності. Хоча на практиці у 234 наведених кейсів місії ООН призвели до появи нових держав (Косово, Східний Тимор), Боснія так і на стала повноцінною державою, а влада в країні належить так званим «трьом конституційним народам»: сербам, боснякам та хорватам (Забара, 2013, с. 38). Лише Хорватія повністю відновила свою територіальну цілісність.

Взагалі питання, чи є міжнародне управління територіями під егідою ООН окупаціями, доволі дискусійне. Значна кількість дослідників феномену окупації погоджуються, що місії ООН є окупаціями (De Brabandere, 2009, p. 124; Stirk, 2009, p. 51; Benvenisti, 2012, p. 62). За словами Е. де Брабандере, «якщо ООН фактично здійснює ефективний контроль і повноваження на території без волевиявлення суверена, це відповідає визначенню окупації, i тому ООН слід розглядати як окупаційну силу» (2009, р. 124).

Дж. Коен (2007, p. 512), навпаки, вважає, що міжнародні адміністрації не підпадають під дію Гаазьких і Женевських правил, оскільки створюються на підставі Статуту ООН. Слід відмітити, що Радбез ООН при запровадженні миротворчих місій ніколи не посилався на право окупації (Benvenisti, 2012, p. 276).

Гуманітарні окупації, як i трансформаційні, прагнуть до реформи політичних інститутів. Боснія, Косово та Східний Тимор отримали нові конституції в результаті окупації, що, за словами Г. Фокса, «залишає мало місця для принципу збереження» (2008, р. 241). Разом з цим, він застережує, що відмова від цього принципу небезпечно стирає грань між окупацією та анексією. «Окупанти користуються обмеженою законодавчою владою саме 
тому, що вони не отримують суверенних прав поваленого режиму. Обмеження їх управлінських повноважень є ознакою їх тимчасового, опікунського статусу» (Fox, 2008, p. 251).

Головна відмінність між цими двома концептуальними підходами полягає в суб’єкті, що здійснює ефективний контроль над територіями: в трансформаційних окупаціях є чітко визначені окупаційні держави (навіть якщо вони діють у складі військового альянсу), тоді як в гуманітарних окупаціях повноваження національного уряду делегуються міжнародним адміністраторам, що діють під егідою ООН, НАТО, ОБСЄ тощо.

Тривалий, складний та дороговартісний шлях управління переліченими територіями, а також критика перехідних адміністрацій за дефіцит демократії та репрезентативності адміністрацій в очах корінного населення, призвели до зменшення мандатів ООН на втручання у внутрішні справи країн-членів. Під час подій Арабської весни, зокрема в Лівії у 2011 році, Радбез ООН обмежив воєнну інтервенцію НАТО необхідністю захисту цивільних осіб, виключивши можливість діяльності окупаційних сил на постійній основі. Однак гібридна окупація Донбасу Російською Федерацією із залученням проросійських маріонеток гостро поставила питання про перегляд політики невтручання ООН та повторної актуалізації миротворчих політикотрансформаційних проектів.

Окупація через третіх осіб (occupation by proxy). Появу концепції окупації через третіх осіб (опосередкованої окупації) пов’язують з рішенням Міжнародного трибуналу щодо колишньої Югославії (МТКЮ) від 7 травня 1997 р. у справі «Прокурор проти Тадіча», в якій судом розглядались обвинувачення, щодо етнічних чисток на території Боснії у 1992 р. В цій справі МТКЮ застосував т.з. тест загального контролю для визначення міжнародної відповідальності колишньої республіки Югославія за дії боснійського серба Душко Тадича під час конфлікту в Боснії, зазначивши, що «фактичний зв’язок органів або представників 3 іноземною державою включає такі обставини, при яких іноземна держава «окупує» певну 
територію або діє на ній виключно через місцеві de facto органи або місцевих представників» (Prosecutor v. Tadic, 1997, para. 584).

Слід зауважити, що перші спроби експлікувати феномен війн «чужими руками» зроблені ще всередині XX ст., коли німецький політолог К. Дойч (1964, p. 102) дав визначення «проксі війни» (proxy war) як міжнародного конфлікту між двома державами, одна 3 яких маскує свою участь за допомогою підтримки тієї чи іншої збройної сили в країні, з якою ця держава веде неоголошену війну. Але в ситуаціях з окупаціями класичний принцип ефективного контролю тривалий час розумівся як безпосередній територіальний контроль окупанта над суверенними територіями іншої держави. Як пише С. Віте, ефективний територіальний контроль означає, що «може статися заміна влади суверена на владу окупанта» $(2009$, р. 74). При цьому, він звертає увагу, що аналогічний поріг застосування принципу ефективного контролю не може бути досягнутий, якщо іноземні сили розташовані за межами відповідного регіону (2009, р. 85).

Окупація через третіх осіб покликана вирішити цю дилему між принципом ефективного контролю та «фізичною відсутністю» військ окупаційної держави (реальною чи удаваною). За коментарем Т. Ферраро (2012, рр. 159-160), в сучасних окупаціях через третіх осіб критерій, що потребує військової присутності ворожих іноземних військ, виконується, коли застосовується теорія непрямого ефективного контролю, оскільки загальний контроль над місцевими органами, що здійснюють контроль над відповідними територіями, перетворює осіб, які належать до цих органів, в «агентів» або «допоміжних осіб» іноземної держави. Такий контроль, що здійснюється над цими місцевими організаціями, відображає реальний та ефективний зв'язок між групою осіб, що здійснюють ефективний контроль, та іноземною державою, що діє через ці сурогатні органи.

У справі Тадіча МТКЮ знизив поріг для привласнення державі поведінки недержавних акторів 3 «ефективного контролю» до «загального контролю» (Ivanel, 2015, p. 53). Суд визначив, що критерій «загального 
контролю» досягнутий, коли іноземна держава «грає роль в організації, координації або плануванні воєнних дій військового угруповання, а не тільки надає фінансову допомогу, здійснює підготовку та надає спорядження або здійснює бойове забезпечення цього угруповання» (Prosecutor v. Tadic, 1997, para. 137). На підставі цього критерію суд встановив, що боснійські серби діяли від імені Федеративної Республіки Югославія.

Пізніше суд підтвердив свою позицію у справі «Прокурор проти Блашкіча», яка стосувалась діяльності Хорватської ради оборони (ХРО), що складалась з організованих збройних груп, створених етнічними хорватами в Боснії. МТКЮ вказав, що Хорватія грала роль окупаційної держави завдяки загальному контролю, який вона здійснювала над ХРО, підтримці, яку надавала, й тісним зв'язкам, які підтримувала з XPO (Prosecutor v. Blaškić, 2000, para. 149).

Аналізуючи справи Тадіча та Блашкіча, можна дійти висновку, що МТКЮ до ознак «організації, координації або планування воєнних дій» відносить: схожість військових структур контролюючої держави та ¥іi маріонетки; проведення збройними групами військових операцій в рамках стратегій, розроблених контролюючою державою (Prosecutor v. Tadic, 1997, para. 151); виплату цією державою зарплат підконтрольним групам; відбір до цих збройних груп лояльних окупанту осіб; видання військовим командуванням контролюючої держави та недержавного суб'єкта однакових за змістом наказів, що стосуються окупованих територій (Prosecutor v. Blaškić, 2000, paras. 101, 117, 118).

Запропонований МТКЮ перелік ознак, що можуть вказувати на загальний контроль, не $є$ вичерпним. Європейський суд 3 прав людини (ЄСПЛ), починаючи зі справи «Ілашку та інші проти Молдови та Росії» (рішення від 8 липня 2004 р.) зробив тест загального контролю ще більш гнучким, розширивши його за межі воєнного контролю у політичну та економічну сфери. За висновком ЄСПЛ, той факт, що Росія мала військовослужбовців та склади озброєння, розміщені на цій території, а 
також мала чіткі комерційні зносини між контрольованими державою військовими інституціями та аналогічними інституціями, що знаходилися в окупованій державі, був важливим. Ці фактори доводять, що, ймовірно окремі суб'єкти, ПМР («Придністровська Молдавська Республіка»), залишалися під ефективною владою, або, принаймні, під визначальним впливом, Російської Федерації: «у будь-якому випадку ... вона (ПМР) виживає завдяки воєнній, економічній, фінансовій та політичній підтримці, яка надається Російською Федерацією» (Ilaşсu and others v. Moldova and Russia, 2004, paras. 387-390, 392).

Хоча ЄСПЛ не використовує термін «окупація через третіх осіб», аналіз його рішень свідчить, що де-факто стан окупації встановлений судом у справах проти Туреччини, Росії та Вірменії, які стосуються, відповідно, територій Північного Кіпру (Loizidou v. Turkey, 1996, paras. 52, 56), Придністров’я та Нагорного Карабаху (Chiragov and others v. Armenia, 2015, para. 186).

Отже, ця концепція стала не просто теоретичною моделлю, а й важливим практичним інструментом для інтерпретації прихованих окупаційних режимів сучасності. О. Гілдер (217, р. 60) з цього приводу висловився, що в епоху гібридних війн захист населення знаходиться під загрозою без повного визнання та здійснення окупації через третіх осіб. О. Задорожній підкреслив, що застосування доктрини загального контролю доводить, що на Донбасі Росія як держава відповідальна за дії «ополчення», оскільки «скеровує його діяльність, надає озброєння, фінансує, безпосередньо керує діями бойовиків» $(2015$, с. 215$)$.

Окупація через третіх осіб як емпірична реальність є найбільш небезпечним різновидом окупацій, оскільки вона заперечує всі три основних компонента: принцип збереження, ефективний контроль територій й тимчасовість окупаційної влади. В сенсі нормативної моделі, вона дозволяє кваліфікувати окремі політичні режими як окупаційні та відрізнити їх від 
інших форм політичної організації суспільств (невизнані держави, несамоврядні території тощо), а також від інших типів окупацій.

Застосовуючи розглянуті концепції окупації, можна здійснити відповідний розподіл усіх існуючих окупаційних режимів на чотири групи (див. табл. 1).

Таблиця 1

\section{Домінуючі типи окупаційних режсмів XXI століття}

\begin{tabular}{|c|c|c|c|c|c|}
\hline & $\begin{array}{r}\text { Часово-прост } \\
\text { режІ }\end{array}$ & $\begin{array}{l}\text { рові рамки } \\
\text { му }\end{array}$ & Суверенні & амки режиму & $T_{-}$ \\
\hline & $\begin{array}{c}\text { окупована } \\
\text { територія }\end{array}$ & $\begin{array}{c}\text { період } \\
\text { режиму }\end{array}$ & $\begin{array}{c}\text { законний } \\
\text { суверен }\end{array}$ & окупант & 1 Иіп окупацп \\
\hline 1 & $\begin{array}{l}\text { Голанські } \\
\text { висоти }\end{array}$ & 1967- т.ч. & Сирія & Ізраїль & пролонгована \\
\hline 2 & Сектор Газа & 1967 - т.ч. & Палестина & Ізраїль & пролонгована \\
\hline 3 & Західний Берег & 1967 - т.ч. & Палестина & Ізраїль & пролонгована \\
\hline 4 & $\begin{array}{l}\text { Східний } \\
\text { Срусалим }\end{array}$ & 1967 - т.ч. & Палестина & Ізраїль & пролонгована \\
\hline 5 & $\begin{array}{l}\text { Північний } \\
\text { Кіпр }\end{array}$ & 1974 - т.Ч. & Кіпр & Туреччина & через третіх осіб \\
\hline 6 & Західна Сахара & 1975 - т.ч. & САДР* & Марокко & пролонгована \\
\hline 7 & $\begin{array}{l}\text { Нагірний } \\
\text { Карабах }\end{array}$ & 1992 - т.ч. & Азербайджан & Вірменія & через третіх осіб \\
\hline 8 & Придністров'я & 1992 - т.ч. & Молдова & Росія & через третіх осіб \\
\hline 9 & $\begin{array}{l}\text { Боснія та } \\
\text { Герцеговина }\end{array}$ & $1995-2003$ & $\begin{array}{l}\text { Боснія та } \\
\text { Герцеговина }\end{array}$ & HATO & гуманітарна \\
\hline 10 & $\begin{array}{l}\text { Східний } \\
\text { Тимор }\end{array}$ & $1999-2002$ & $\begin{array}{l}\text { Східний } \\
\text { Тимор }\end{array}$ & $\mathrm{OOH}$ & гуманітарна \\
\hline 11 & Косово & $1999-2008$ & Косово & $\mathrm{OOH}$ & гуманітарна \\
\hline 12 & Бадме & $2000-2018$ & Еритрея & Ефіопія & пролонгована \\
\hline 13 & Афганістан & 2001 & Афганістан & США & трансформаційна \\
\hline 14 & Ірак & $2003-2005$ & Ірак & $\begin{array}{l}\text { США, } \\
\text { Великобританія }\end{array}$ & трансформаційна \\
\hline 14 & Абхазія & 2008 - т.ч. & Грузія & Росія & через третіх осіб \\
\hline 15 & $\begin{array}{l}\text { Південна } \\
\text { Осетія }\end{array}$ & 2008 - т.Ч. & Грузія & Росія & через третіх осіб \\
\hline 16 & Крим & 2014 - т.ч. & Україна & Росія & пролонгована \\
\hline 17 & ОРДЛО** & 2014 - т.ч. & Україна & Росія & через третіх осіб \\
\hline
\end{tabular}

* Сахарська Арабська Демократична Республіка

** Окремі райони Донецької та Луганської областей 
Слід зазначити, що запропонований поділ відображає домінуючий тип окупації на відповідній території, хоча перипетії встановлення окремих окупаційних режимів включали елементи інших типів окупації. Наприклад, вторгнення Туреччини до Кіпру у 1974 р. супроводжувалось класичною воєнною окупацією, проте вже у перших справах проти Туреччини, пов'язаних з цією окупацією, що розглядались ЄСПЛ, уряд Туреччини відмовився нести відповідальність за дотримання прав населення окупованої території, стверджуючи, що його збройні сили діють виключно в тісній взаємодії та від імені нібито незалежної та автономної влади «Турецької Республіки Північного Кіпру» (ТРПК) (Loizidou v. Turkey, 1996, para. 54). У Криму, навпаки, окупація півострова наприкінці лютого-початку березня 2014 р. розпочалась, значною мірою, за допомогою «третіх осіб». Окрім залучення т.з. «зелених чоловічків» (військовослужбовців без розпізнавальних знаків), Росія екіпірувала, озброїла та керувала діями «казаків» та інших парамілітарних угруповань, направлених нею ж 3 території РФ для сприяння окупації півострова та маскування дій російської армії (Задорожній, 2015, с.92). В подальшому, анексія півострову та утворення нових «суб’єктів федерації»: «Республіки Крим» і «міста федерального значення Севастополя» зафіксували встановлення на півострові пролонгованого окупаційного режиму.

Дискусійними залишаються питання наявності статусу й прав законного суверена відповідних територій у Косово, Західної Сахари, Палестини, здійснення ефективного контролю Ізраїлем над Сектором Газа тощо. Це лише підтверджує необхідність подальших концептуальних інтерпретацій еволюціонуючих окупаційних режимів сучасності.

Висновки. Наприкінці XX - на початку XXI століття перед вченими, політиками, юристами стояли складні завдання розв’язання протиріч між традиційним міжнародним правом, яке покликано захищати територіальну цілісність й суверенну рівність усіх держав світу, та пошуком легітимних підстав для обмеження державного суверенітету в ім'я гуманітарного захисту 
населення та ліберальних трансформацій авторитарних режимів. Трансформаційні та гуманітарні окупації стали моделями управління територіями, що намагались на практиці вирішити складну дилему між обмеженнями у здійсненні права окупації та трансформаційними цілями акторів окупаційних режимів. Незважаючи на явне прагнення до зміни існуючого політичного порядку на окупованих територіях, окупанти чітко усвідомлювали свій тимчасовий статус. Тривалість таких окупаційних режимів, зазвичай, не перевищувала 3-5 років.

У той же час окремі держави продовжують використовувати воєнні інтервенції та окупації чужих територій як механізм силового забезпечення власних інтересів. Пролонговані окупації та окупації через третіх осіб $є$ емпіричною реальністю цієї політики. Явна нелегітимність влади таких окупантів вимагає від міжнародної спільноти застосування ефективних заходів примусу з метою припинення триваючих окупаційних режимів та відновлення суверенітету постраждалих держав.

Нові нормативні рамки здійснення окупантами влади на підконтрольних територіях $€$ спробою компромісу між базовими обмеженнями Гаазької доктрини окупації та реальною політикою акторів окупаційних режимів. Однак, гра в умиротворення окупантів призводить до шкідливих наслідків й появи як кількісно, так і якісно нових окупацій, що загрожують світовому порядку та актуалізують пошуки нових концептуальних підходів задля їх нормативного обмеження.

\section{ЛІТЕРАТУРА}

1. Забара, В.В., 2013. Політичні перетворення «післядейтонської» Боснії і Герцеговини (1996-2012 рр.): проблеми періодизації. Історичний архів, 10, с. 38-44.

2. Задорожній, О.В. 2015. Порушення агресивною війною Російської Федерачї̈ проти України основних принципів міжнародного права. Київ: К.І.С.

3. Законодавство України, 2017. IV Конвенція про закони і звичаї війни на суходолі від 18.10.1907 та додаток до неї: Положення про закони $i$ звичаї війни на суходолі. [online] Доступно: https://zakon.rada.gov.ua/laws/show/995_222 [Дата звернення: 15 січень 2019]. 
4. Кіссінджер, Г. 2017. Світовий порядок. Роздуми про характери націй в історичному контексті. Київ: Наш Формат.

5. Куц, Г.М., 2011. Трансформаційні інтенції лібералізму. Гілея: науковий вісник: Збірник наукових праць, 54(3), с. 632-639.

6. Benvenisti, E. 2012. The international law of occupation. 2nd ed. Oxford, United Kingdom: Oxford University Press.

7. Bhuta, N., 2005. The antinomies of transformative occupation. European journal of international law, 16(4), pp. 721-740.

8. Chinkin, C., 2008. Laws of occupation. [online] Available at: http://www.arso.org/ChinkinPretoria2008.htm [Accesssed: 15 January 2019].

9. HUDOK, 2015. Chiragov and others v. Armenia. [online] Available at: http://hudoc.echr.coe.int/eng?i=001-155353 [Accessed: 15 January 2019].

10. Cohen, J., 2007. The role of international law in post-conflict constitution-making: toward a jus post bellum for «interim occupations». New York law school review, 51, pp. 497-532.

11. De Brabandere, E. 2009. Post-conflict administrations in international law: international territorial administration, transitional authority and foreign occupation in theory and practice. Leiden: Martinus Nijhoff.

12. Deutsch, K., 1964. External involvement in internal wars. In: H. Eckstein, ed. Internal war: problems and approaches. New York: Free Press. pp. 100-110.

13. Ferraro, T., 2012. Determining the beginning and end of an occupation under international humanitarian law. International review of the Red Cross, 94(885), pp.133-163.

14. Fox, G. 2008. Humanitarian Occupation. Cambridge, United Kingdom: Cambridge University Press.

15. Gilder, A., 2017. Bringing occupation into the 21st century: the effective implementation of occupation by proxy. Utrecht Law Review, 13(1), pp. 60-81.

16. Loizidou v. Turkey,1996. [online] Available at: http://hudoc.echr.coe.int/eng?i=001-58007 [Accesssed: 15 January 2019].

17. Ilaşcu and others v. Moldova and Russia, 2004. [online] Available at: http://hudoc.echr.coe.int/eng?i=001-61886 [Accesssed: 15 January 2019].

18. Ivanel, B., 2015. Puppet states: a growing trend of covert occupation. Yearbook of international humanitarian law, 18, pp. 43-65.

19. Prosecutor v. Blaškić, 2000. [online] Available at: http://www.icty.org/x/cases/blaskic/tjug/en/bla-tj000303e.pdf [Accesssed: 15 January 2019].

20. Prosecutor v. Tadić, 1997. [online] Available at: http://www.icty.org/x/cases/tadic/tjug/en/tad-tsj70507JT2-e.pdf [Accesssed: 15 January 2019].

21. Roberts, A., 1990. Prolonged military occupation: the Israeli-occupied territories since 1967. The American journal of international law, 84(1), pp. 44-103.

22. Roberts, A., 2006. Transformative military occupation: applying the laws of war and human rights. The American journal of international law, 100(3), pp. 580-622.

23. Scheffer, D., 2003. Beyond occupation law. The American journal of international law, 97(4), pp. 842-860.

24. Stirk, P. 2009. The politics of military occupation. Edinburg: Edinburg University Press. 
25. United Nations Security Council, 2003. Resolution 1483. The situation between Iraq and Kuwait. [online] (Last updated 22 May 2003) Available at: http://unscr.com/en/resolutions/1483 [Accesssed: 15 January 2019].

26. Vité, S., 2009. Typology of armed conflicts in international humanitarian law: legal concepts and actual situations. International review of the Red Cross, 91(873), pp. 69-94.

\section{Інформація про автора}

Размєтаєв Андрій Сергійович - аспірант кафедри політології, соціології і культурології Харківського національного педагогічного університету імені Г.С. Сковороди; e-mail: andrey.razmetaev@gmail.com; ORCID: https://orcid.org/0000-0003-0476-051X.

Стаття надійшла до редакції: 23.01.2019 р. Прийнята до друку: 06.02.2019 р. 